\title{
LA CONSTITUCIÓN CULTURAL
}

JAVIER TAJADURA

Profesor Titular de E. U. Universidad 


\section{SUMARIO}

1. Introducción. 2. El concepto de Constitución cultural. 3. El Estado de CulTURA. 4. El CONCEPTO DE CULTURA: UNIVERSALISMO VERSUS PARTICULARISMO. 4. 1. La concepción universalista de la Cultura heredera de la Revolución Francesa. 4.2. La concepción particularista derivada del Romanticismo alemán. 4.3. Semejanzas, diferencias y compatibilidad de las dos nociones expuestas. 5. LAS dOS NOCIONES DE CULTURA CONTENIDAS EN LA CONSTITUCIÓN DE 1978. 6. El pluRalismo cultural en la Constitución. 6.1. La libertad cultural como presupuesto. 6.2. Manifestaciones del pluralismo. 6.3. Pluralismo y unidad: los artículos 148.1.17 y 149.2 de la Constitución. 7. EL PROGRESO DE LA CULTURA. 7.1. Manifestaciones generales del principio. 7.2. El derecho a la cultura: el artículo 44 de la Constitución. 7.3. La función cultural del Estado. 8. ¿Es nUestra Constitución cultural Relativista? 9. Cultura y democracia. 10. Conclusiones. 


\title{
LA CONSTITUCIÓN CULTURAL
}

POR

\author{
JAVIER TAJADURA \\ Profesor Titular de E. U. Universidad
}

\begin{abstract}
"Llegará un tiempo en el que la cultura se habrá extendido con igualdad y sobre todos los lugares de un mismo territorio y entre todas las clases de una misma sociedad; en el que todas las ciencias y todas las aplicaciones de la ciencia se habrán emancipado igualmente del yugo de todas las supersticiones o del veneno de las falsas doctrinas; en el que cada hombre, en fin, encontrará en sus propios conocimientos, en la rectitud de su espíritu, armas suficientes para rechazar todas las añagazas de la charlatanería; pero estos tiempos están lejanos aún; nuestra finalidad debe ser prepararlos, acelerar su advenimiento."
\end{abstract}

(Juan Antonio Maria Nicolás de Caritat, MARQués de CondorCet)

\section{INTRODUCCIÓN}

La irrupción de la cultura en el constitucionalismo es relativamente tardía. Por lo que respecta a nuestro país, ni una sola de las Constituciones españolas del siglo xIX incluyeron en su articulado la voz cultura. Cierto es que los textos constitucionales regularon materias conexas como la educación, la imprenta o la lengua, pero nunca hablaron expresamente de cultura. El término "cultura", curio- 
samente, únicamente aparece en algunos Preámbulos constitucionales:

a) En el Discurso Preliminar de Argüelles se dice: «El inmenso número de originarios de África establecidos en los países de ultramar, sus diferentes condiciones, el estado de civilización y cultura en que la mayor parte de ellos se halla en el día, han exigido mucho cuidado $y$ diligencia para no agravar su actual situación».

b) La Exposición de Motivos a la Reina Gobernadora que antecede al Estatuto Real de 1834 contiene el siguiente párrafo: «Mas así que por un concurso afortunado de diferentes causas, empezó a desarrollarse la civilización y la cultura, mejorándose insensiblemente la condición del pueblo, fueron creciendo en importancia las clases medias de la sociedad, y después de adquirir libertades y franquicias municipales, aspiraron a su vez a tener también voto en las asambleas generales de la nación".

Esta ausencia de la cultura en nuestras constituciones decimonónicas se dio también en el ámbito del constitucionalismo comparado. La recepción constitucional de la cultura tuvo que esperar hasta el siglo xx. La primera acogida tuvo lugar en México.

En España, fue la Constitución republicana la que introdujo la cultura en el sistema constitucional. "Familia, economía y cultura" era el encabezamiento del capítulo II del Título III de dicho texto. A las "características culturales" de las regiones se refería el artículo 11. Y los artículos 48 y 50 aludían respectivamente al "servicio de la cultura" y a la "expansión cultural de España». De hecho, el tema cultural recibió un tratamiento apasionado en las Cortes Constituyentes, debido a la fuerte polémica que suscitó el debate sobre la «unidad cultural de España»'.

1 En los discursos pronunciados esos días en las Cortes Constituyentes se aprecia de forma clara que se ha asumido el importantísimo papel que para la vida del Estado juega la cultura. Esto es algo que ya está presente en el Discurso de Argüelles de 1812, es fruto del espíritu ilustrado, pero no es hasta ahora cuando irrumpe con esta fuerza en los debates constitucionales. $Y$ esto es así porque, ahora, ha hecho su entrada una noción distinta de cultura: la noción particularista. En 1812 sólo se pensaba en la concepción universalista de la cultura, cultura y civilización eran términos parejos. En 1931 la polémica está originada por la entrada en juego de ideologías nacionalistas. Posteriormente analizaremos las diferencias existentes entre las dos nociones aludidas. Cortes Constituyentes, número 59 , de 20 de octubre de 1931; número 60, de 21 de octubre de 1931; número 61, de 22 de octubre de 1931. 
Ulteriormente, todas las constituciones europeas posteriores a la Segunda Guerra Mundial han constitucionalizado la cultura².

Nuestra Constitución de 1978 no es, en este aspecto, una excepción. Son numerosos los preceptos del texto constitucional que recogen el sustantivo "cultura" y el adjetivo "cultural»: Preámbulo, arts. 9.2, 25.2, 44, 46, 48, 50, 143.1, 148.1.17, 149.1.28 y 149.2. En otros muchos $(3,20,27 \ldots)$ aparecen palabras cuya conexión con la noción de cultura es evidente: archivos, arte, artesanía, bibliotecas, ciencia, conservatorios de música, educación, investigación, lenguas, literatura, museos, patrimonio histórico-artístico, patrimonio monumental, técnica, tradiciones.

La profusión de preceptos que hacen referencia a lo cultural ha llevado a la doctrina a estudiar nuestra "Constitución cultural" y a considerar la posible calificación de España como "Estado de Cultura». EI análisis del contenido de la constitución cultural española es el objeto de esta exposición.

\section{EL CONCEPTO DE «CONSTITUCIÓN CULTURAL»}

La expresión "Constitución cultural" es utilizada con frecuencia por los autores italianos. PIZZORUSSO define el concepto con gran amplitud: "Al lado del conjunto de principios que la Constitución dedica a las relaciones económicas deben situarse una serie de disposiciones de no menos trascendencia encaminadas a asegurar una protección básica a la vida humana considerada como valor en sí, al margen del uso que se haga de los recursos humanos en atención a fines políticos o económicos. Se da así entrada a una nueva dimensión de las garantías constitucionales cuyo núcleo esencial se halla en la protección de la libertad personal y de los demás derechos fundamentales vinculados de diversa manera a la misma y que se manifiesta, ante todo, en un conjunto de reglas generales tendentes a crear una situación ambiental que facilite lo más posible el ejercicio de las libertades indi-

2 Según Prieto de Pedro, las constituciones portuguesa de 1976 y española de 1978 son "el modelo de la redacción más exhaustiva, sistemática y compleja que sobre dicho tema se ha realizado en un texto constitucional", en "Consideraciones sobre la enseñanza en la Constitución", Lecturas sobre la Constitución, UNED, Madrid, 1978, tomo II, pág. 505. 
viduales. En tanto que estas reglas generales, así como el principio de garantía de la persona y sus diversas especificaciones, encuentra su fundamento en una serie de opciones en las que se acepta un determinado modelo de cultura - y un consiguiente rechazo de otros modelos contrapuestos-, parece oportuno integrar toda esta temática bajo la noción común de "constitución cultural", destacando bajo esta rúbrica una dimensión distinta de la definida como "constitución económica", por más que los nexos e interferencias entre una y otra problemática no sean en modo alguno infrecuentes" ${ }^{3}$.

En nuestro país en los últimos años se aprecia también un creciente uso de tal expresión por la doctrina. TORRES DEL MORAL al comentar el artículo 44 de nuestra Constitución escribe: "Generalmente, podríamos decir que en todo texto fundamental, al menos en el constitucionalismo más reciente, coexisten una Constitución política, una Constitución económica y una Constitución cultural. Tal sucede en la Constitución españolas ${ }^{4}$.

La Constitución cultural viene definida por la interpretación sistemática de todos los preceptos que se refieren a la realidad pluridimensional en que la cultura consiste. Realidad pluridimensional porque en la Constitución la cultura presenta una triple faceta:

a) En primer lugar, la cultura es un ámbito de la vida humana, como lo es el político, el económico o el social. Tal es el sentido del párrafo quinto del Preámbulo al aludir a las dos dimensiones del progreso: la económica y la cultural. Dicha perspectiva se encuentra reflejada, de forma general, en el artículo 9.2, que atribuye a los poderes públicos la tarea de facilitar la participación ciudadana en la vida política, económica, cultural y social. El artículo 48 proyecta el principio a un sector social determinado: la juventud.

b) En segundo lugar, la cultura es un derecho. Ello se refleja en el artículo 44 de la Constitución, del que nos ocuparemos después. También en el artículo 25.2, en relación con los presos, y en el artículo 50 , referido a la tercera edad.

3 Pizzorusso, A.: Lecciones de Derecho constitucional, traducción de J. Jiménez Campo, CEC, Madrid, 1984, vol. I, pág. 193.

" Torres del Moral, A.: "Comentario al artículo 44 de la Constitución", en Comentarios a las leyes políticas, dirigido por Óscar Alzaga, Edersa, Madrid, 1984, tomo IV, pág. 210. También en Principios de Derecho constitucional español, Servicio de Publicaciones de la Facultad de Derecho de la Universidad Complutense, 3. ed., Madrid, 1992, vol. I, pág. 88. 
c) Por último, la cultura es una función del Estado, como se desprende claramente del importantísimo artículo 149.2, que también estudiaremos. A la función protectora de las "culturas" y promotora de la "cultura» alude el Preámbulo. Para su cumplimiento el Estado cuenta con una notable variedad de instrumentos: artículos 20, 27, 43.3, 45, $46,51.2$.

La aparición del elemento cultural en el constitucionalismo más reciente, la existencia de una constitución cultural pone de manifiesto, según PRIETO DE PEDRO, "una reciente sensibilidad, un énfasis nuevo en la valoración de este tema, un intento de aprehender jurídicamente la plenitud y la globalidad de su concepto metajurídico, desbordándose el estrecho horizonte constitucional previo, que se circunscribía a considerar en lo cultural la instrucción pública y, en parte, la libertad de imprenta y poco más»"

\section{EL ESTADO DE CULTURA}

Si bien la expresión Estado de Cultura no se halla expresamente recogida en el texto constitucional, el amplio contenido cultural del mismo, anticipado y sintetizado en el Preámbulo, nos permite afirmar que España se constituye en un Estado de Cultura.

El origen de la expresión "Estado de Cultura» se sitúa en 1806, en la obra de FICHTE Die Grudzüge des gegenwärtigen Zeitalters. EI pensador alemán empleó la expresión en un sentido muy amplio ${ }^{6}$. La expresión adquiere sentido jurídico a partir de BLUNTSCHLI, quien en su trabajo Allgemeines Staatsrecht, publicado en 1852, clasifica a los Estados en Monarquías, Repúblicas o Estados de Cultura. "Los intere-

5 Prieto de Pedro, J.: Cultura, culturas y Constitución, Congreso de los Diputados-Centro de Estudios Constitucionales, Madrid, 1992, pág. 204. Aluden a la "Constitución cultural", entre otros, BAssols CoMA, M.: "El patrimonio histórico español: aspectos de su régimen jurídico", RAP, n. ${ }^{\circ} 114,1987$, pág. 94 . Fossas, E.: Regions i sector cultural a Europa. Estudi comparat: Bélgica, França, Itàlia i Espanya, Institut d'Estudis Autonòmics, Generalitat de Catalunya, Barcelona, 1990, pág. 19. Pérez Moreno, A., en el prólogo al libro de Barrero Rodriguez, C.: La ordenación jurídica del patrimonio histórico, Civitas, Instituto García Oviedo, Madrid, 1990, pág. 19.

6 Estados de cultura eran los Estados europeos occidentales surgidos en tiempo del cristianismo. 
ses culturales pueden determinar de forma especial la vida de un pueblo y es entonces cuando surgen los Estados de Culturan' ${ }^{7}$.

La recepción constitucional de la expresión "Estado de Cultura» tuvo lugar también en Alemania un siglo más tarde. El artículo 3 de la Constitución del Estado de Baviera, de 1946, estableció: "Baviera es un Estado de Derecho, de Cultura y social que sirve al bien común".

En España ${ }^{8}$, a partir de la Constitución de 1978, se advierte también una creciente presencia de la expresión «Estado de Cultura» en la literatura jurídica. LUCAS VERDÚ, al analizar la cláusula Estado de Derecho contenida en el artículo 1 de la Constitución, afirma: "Cabe hablar del Rechtsstaat como Kulturstaat, porque el imperio de la ley es principio de cultura» ${ }^{9}$. y más adelante dice: "El Estado social y democrático, diseñado por nuestra Constitución, puede aparecer como Estado de Cultura en tanto que respete los valores que propugna (libertad, justicia, igualdad, pluralismo político) sin otros límites que los señalados en los artículos 10.1 y $15 \%$. Al contrastar las exigencias que el Estado de Cultura implica con la realidad social, advierte críticamente: «El Estado de Cultura no puede consentir los ataques a la dignidad de la persona ni a su integridad moral ${ }^{10}$. No puede tolerarlos porque ello supondría atentar contra su fundamento ${ }^{11}$.

7 Jung, O.: Zum Kulturstaatsbegriff, Verlag Anton Hain, Meisenheim am Glan, 1976, págs. 10-30. Tomo la cita de Prieto de Pedro, Cultura..., cit., pág. 213.

s En España, la idea aparece ya en la obra de LegAz LACAMBRa, que lo concibe como uun Estado que se subrogaría a la Iglesia como educador del pueblo y defensor de la moralidad", en "Estado de Derecho", Revista de Administración Públi$c a, n .{ }^{\circ} 6,1951$, págs. 17 y ss. pág. 355.

9 Lucas Verdú, P.: Curso de Derecho Político, vol. IV, Tecnos, Madrid, 1984,

10 Lucas Verdú, P.: Curso..., op. cit., vol. IV, pág. 356. TorRes del Moral, A., dedica un capítulo de su manual "Principios de Derecho constitucional español» al Estado de Cultura. Principios..., op. cit., pág. 86.

11 Con estas palabras concluye FinkIELKRAut su brillante ensayo sobre la cultura, La défaite de la pensée (Editions Gallimard, París, 1987). Apuntan con gran precisión los dos obstáculos a que la consecución de un auténtico Estado de Cultura habrá de hacer frente: los particularismos excluyentes y la mercantilización de la cultura: "La barbarie ha acabado por apoderarse de la cultura. A la sombra de esa gran palabra, crece la intolerancia al mismo tiempo que el infantilismo. Cuando no es la identidad cultural la que encierra al individuo en su ámbito cultural y, bajo pena de alta traición, le rechaza el acceso a la duda, a la ironía, a la razón - a todo lo que podria sustraerle de la matriz colectiva-, es la industria del ocio, esta creación de la era técnica que reduce a pacotilla las obras del espíritu (o, como se dice en América, de entertainment). $Y$ la vida guiada por el pensamiento cede suavemente su lugar al terrible y ridículo cara a cara del fanático y del zombien. FinKIELKRAUT, A.: La derrota del pensamiento, Anagrama, Barcelona, 1987, pág. 139. La existencia de 
El sintagma que nos ocupa ha llegado incluso hasta la jurisprudencia del Tribunal Constitucional de la mano de un voto particular a la sentencia de 13 de febrero de 1981: "Con ella el Estado, en cuanto Estado de Cultura, trata de garantizar el libre cultivo de la ciencia y su libre transmisión por vía docente en todos los grados e instituciones del sistema educativo.... ${ }^{12}$.

Llegado este momento de la exposición es hora de preguntarse: ¿por qué hablar de Estado de Cultura? ¿Es ésta una expresión necesaria o una noción inútil, como dijera no hace mucho GIANNINI respecto a la fórmula "Estado Social"? ${ }^{13}$. En este sentido, hay que decir que aunque el artículo 1.1 de la Constitución no hable de Estado de Cultura, éste es deducible fácilmente tanto de los enunciados preambulares que señalan como objetivos básicos de la nación la protección de las culturas de los pueblos de España y la promoción del progreso de la cultura, como de la proyección de los mismos en numerosos preceptos del texto articulado.

Además, las otras notas definitorias del Estado son insuficientes para captar la esencia del Estado de Cultura:

a) Por lo que se refiere a la cláusula Estado de Derecho hemos de señalar que las libertades culturales han ido con retraso respecto a otras libertades-autonomía clásicas. La tortuosa historia de las libertades científica y de cátedra durante el siglo XIX son prueba de ello ${ }^{14}$

b) La fórmula Estado democrático presenta dos problemas distintos y que son puestos de manifiesto por los seguidores de las dos concepciones que sobre la Cultura se han sostenido en la Historia del pensamiento. Para los defensores de la noción particularista de la cul-

estos peligros nos pone de manifiesto que el Estado de Cultura es un concepto tendencial. La lucha por el Estado de Cultura requiere un combate permanente en varios frentes. Combate que tiene lugar simultáneamente con la lucha por la democratización de la sociedad.

12 F. j. 11.

13 Gianninı, M. S.: "Stato sociale: una nozione inutile", Scritti in onore di Constantino Mortati, Giuffrè, Milán, 1977, vol. I, págs. 144 y ss.

${ }_{14}$ PRIETO De Pedro se refiere también al tratamiento del teatro: «Otro botón de muestra, no tan conocido pero de devenir no menos espinoso, es el del teatro, el de la libertad escénica. ¿No es una evidencia patente de lo que decimos el que preclaros iuspublicistas del siglo pasado, mientras rechazaban la censura previa para la prensa, estuvieran, empero, dispuestos a cerrar los ojos ante intervenciones previas sobre este medio en aras de ver en él, como decían, un instrumento de 'moralidad y buenas costumbres para el pueblo'?". Cultura..., op. cit., págs. 219-220. Expósıto, E.: La libertad de cátedra, Tecnos, Madrid, 1995, págs. 17 y ss. 
tura, el Estado democrático no garantiza la «democracia cultural interna». De hecho, la aplicación de los principios de igualdad y de mayoría ha conducido a la asimilación o uniformidad cultural. El pluralismo cultural necesita más garantías. El otro problema, puesto de relieve por los partidarios de la noción universalista de cultura, consiste en que en nombre del principio democrático se otorgue el calificativo de cultural a aquello que no lo es, a aquello que en vez de formar el espíritu lo embrutece. De hecho el relativismo cultural es la gran amenaza que se cierne sobre el Estado de Cultura ${ }^{15}$.

c) Por último, en la expresión Estado Social ha primado la problemática socio-económica sobre la socio-cultural. Las tareas culturales del Estado han quedado relegadas por la consecución de objetivos económicos ${ }^{16}$. Los derechos culturales no siempre encuentran fácil encaje en los derechos sociales.

Cabe alegar que estas insuficiencias no fueron tales, sino que se deben al carácter histórico que revisten los derechos fundamentales ${ }^{17}$ y que en ese sentido las exigencias culturales surgen en una etapa posterior del desarrollo del Estado social, democrático y de Derecho. Esto es cierto. Pero no lo es menos que la aparición de dichas exigencias, de nuevas demandas en el ámbito de lo cultural, determinan un cambio cualitativo en la concepción de las relaciones entre Estado y cultura ${ }^{18}$. Ese cambio cualitativo justifica la juridificación de la nueva fórmula que completa a los demás calificativos del Estado: Estado de Cultura.

En conclusión, debemos destacar que el Estado de Cultura refuerza las garantías de existencia libre y plural de la cultura, asumiéndola en su totalidad, corrigiendo así los enfoques fragmentarios propios del pasado y promoviendo las condiciones necesarias para su progreso y para su accesibilidad a todos los miembros de la comunidad nacional ${ }^{19}$.

15 Sobre el primer problema, Prieto de Pedro, J.: Cultura..., op. cit., pág. 221; sobre el segundo, FinKielKraUt, A.: La derrota del pensamiento, Anagrama, Barcelona, 1987, págs. 124-130.

16 Torres del Moral trata este tema en "Comentarios al artículo 44...», op. cit., pág. 206. Tambien, AbENDROTH, W.: “El Estado de Derecho democrático y social como proyecto políticon, en El Estado social, CEC, Madrid, 1986, págs. 40-41.

17 Peces Barba, G.: "Los derechos fundamentales como concepto histórico», en Curso de Derechos Fundamentales, Eudema, Madrid, 1991, págs. 99-125.

18 Prieto de Pedro, J.: Cultura..., op. cit., pág. 223.

19 "Al asumir los poderes públicos la difusión de la Cuitura, su desarrollo tiene que pasar a constituir una de las finalidades del Estado". GálVEZ, J.: "Comentario al artículo 44", en Comentarios a la Constitución (Garrido Falla, F., dir.), Civitas, 2. ed, Madrid, 1985, pág. 803. 
El Estado de Cultura se levanta, pues, sobre dos pilares: libertad y progreso. Ambos se hallan reflejados en el texto constitucional, tanto en el Preámbulo como en numerosos preceptos del texto articulado ${ }^{20}$.

\section{EL CONCEPTO DE CULTURA: UNIVERSALISMO VERSUS PARTICULARISMO}

Llegados hasta este punto no parece conveniente seguir hablando de cultura sin definir previamente qué entendemos por tal. El objetivo que perseguimos es determinar la noción constitucional de Cultura y para ello hemos de recurrir primero a la ayuda de otras ciencias. Pero como veremos, dicho estudio no nos facilitará la tarea, sino que nos planteará problemas de muy difícil solución.

El seguimiento del itinerario recorrido por el concepto de cultura en todas las ramas del saber científico es una tarea que desborda las pretensiones de nuestro trabajo. Un sucinto examen de las principales teorías construidas por la Filosofía y la Antropología nos será suficiente para comprender la polisemia del concepto y de esa manera intentar establecer la noción constitucional de Cultura. Noción compleja, pues ya desde el mismo Preámbulo la Constitución recoge el término cultura con dos significados distintos, que son expresión, como veremos, de las dos concepciones enfrentadas sobre la Cultura que han mantenido los filósofos y antropólogos.

\subsection{La concepción universalista de la Cultura heredera de la llustración francesa}

Cabe situar en los estudios de Historia Universal realizados en la Alemania del siglo XVIII el origen del concepto que nos ocupa. Dichos estudios estaban guiados, como señala TORRES DEL MORAL, por el íntimo convencimiento de que la historia humana era la historia del pro-

20 Prieto de Pedro considera "la libertad cultural" y uel desarrollo de la culturan los dos principios fundamentales del Estado de Cultura. Consideraciones sobre..., op. cit., pág. 507. 
greso de la humanidad. El término "cultura" sirvió precisamente para dar nombre a esa evolución del progreso ${ }^{21}$.

Una célebre frase de RENAN basta para comprender en qué consiste la concepción universal de la cultura: "Antes de la cultura francesa, la cultura alemana, la cultura italiana, está la cultura humana»"22.

Desde el Renacimiento hasta la época de las luces el progreso de la Humanidad consistió en liberar el espíritu humano de la verdad revelada y de los dogmas religiosos ${ }^{23}$. Se trataba de que el hombre sólo rindiera cuentas a su razón. El concepto de Cultura, como tantos otros conceptos fundamentales para el hombre contemporáneo, es fruto, pues, del pensamiento ilustrado, del espíritu de las Luces. Como señala VON WIESE, la llustración supuso la sustitución del ideal formativo cristiano por el humano. "La idea de cultura sustituye la idea del reino de Dios" ${ }^{24}$. La frase de RENAN, arriba citada, supone un nuevo avance en la lucha contra el oscurantismo, pues implica liberar al hombre de la comunidad en que se arraiga, $o$, lo que es lo mismo, de las cadenas de la tradición local. FINKIELKRAUT señala cómo con esta distinción entre cultura nacional y cultura universal, RENAN «opone el espíritu de Goethe a la visión del mundo instaurada por el nacionalismo alemán $»^{25}$.

Para GOETHE, en ningún caso la cultura humana debía reducirse a la suma de las culturas particulares. A esta conclusión llega al final de su vida, en 1827, leyendo una novela china. La lectura de la misma le produce perplejidad. Y la causa de su sorpresa no es el exotismo de la obra, sino su proximidad. Proximidad con su propia obra y con otras importantes obras producidas en Europa. De esta manera, GOETHE, en la plenitud de su vida intelectual, se percató de que "arraigados en un suelo, anclados en una época, datados y situados, los hombres podían escapar de todos modos a la fatalidad de los particularismos. Se podía apelar contra la división: existían lugares - los libros- en los que la

21 Torres del Moral, A.: “Comentarios al artículo 44...», op. cit., pág. 200.

22 Renan: ¿Qué es una nación? Traducción de R. Fernández Carvajal, IEP, Madrid, 1957. "No abandonemos el principio fundamental de que el hombre es un ser razonable y moral antes de estar acantonado en tal o cual lengua, antes de ser miembro de tal o cual raza, o adherente a tal o cual cultura», pág. 100.

${ }_{23}$ Bury, J.: La idea de progreso, traducción de E. Díaz y J. Rodríguez, Alianza, Madrid, 1971. NisBet, R.: Historia de la idea de progreso, traducción de E. Hegewicz, Gedisa, Barcelona, 1981.

${ }^{24}$ VON WIESE, B.: La cultura de la llustración, traducción de E. Tierno Galván, CEC, Madrid, 1979, pág. 50.

25 FinkIelKRaut, A.: La derrota..., op. cit., pág. 37. 
humanidad podía dominar su desmigajamiento en una miríada de espíritus locales ${ }^{26}$. Por encima de las particularidades nacionales está la Cultura humana.

En el ámbito de la Antropología fue TYLOR, en 1871, el primero que propuso una definición formal de cultura en sentido amplio: "La cultura... es aquel todo complejo que incluye el conocimiento, las creencias, el arte, la moral, el derecho, las costumbres y cualesquiera otros hábitos y capacidades adquiridos por el hombre en cuanto miembro de la sociedad. La situación de la cultura en las diversas sociedades de la especie humana, en la medida en que puede ser investigada según principios generales, es un objeto apto para el estudio de las leyes del pensamiento y la acción del hombre ${ }^{27}$. He aquí reflejada la concepción universalista, acumulativa, de la cultura ${ }^{28}$.

En el mismo sentido, uno de los más célebres seguidores de TyIor, MORGAN escribió: "Podemos asegurar ahora, apoyándonos en pruebas irrefutables, que el período del estado salvaje ha precedido al periodo de barbarie en todas las tribus de la humanidad, de la misma manera que sabemos que la barbarie ha precedido a la civilización. La historia de la humanidad es una en cuanto a origen, una en cuanto a experiencia, una en cuanto a progreson ${ }^{30}$.

Como advierte GOODENOUGH, "según este punto de vista las sociedades no tenían culturas separadas, sino una mayor o menor participación en el desenvolvimiento de la cultura general creada $y$ desarrollada hasta el momento por la humanidad como un todo. El objeto de la antropología cultural era tratar de reconstruir los pasos o etapas que habían señalado el crecimiento de la cultura. Las sociedades con tecnologías más simples y los sistemas políticos menos elaborados re-

26 Finkielkraut, A.: La derrota..., op. cit., pág. 38. En Escritos sobre el Arte encontramos un párrafo que sintetiza el optimismo del pensamiento de GOETHE: "Se alcanzará probablemente una tolerancia generalizada si se deja en paz lo que constituye la particularidad de los diferentes individuos humanos y de los diferentes pueblos, y uno se convence de que la característica distintiva de lo que es realmente meritorio reside en su pertenencia a toda la humanidad". Citado por FinKIELKRAUT, A.: La derrota..., op. cit., pág. 41.

${ }_{27}$ TYLOR, E. B.: "La ciencia de la cultura" (1871), en KAHN, J. S., El concepto de cultura: textos fundamentales, Anagrama, Barcelona, 1975, pág. 29.

${ }_{28}$ Esta definición sería la seguida por la posteriormente llamada "escuela evolucionista". Sus continuadores fueron Morgan y SPENCER. KHAN, J. S.: "Introducción», en El concepto..., op. cit., pág. 10.

29 Morgan, La sociedad arcaica, citado por Finkielkraut, A.. en La derrota..., op. cit., pág. 59. Apoyado en las teorias de MORGAN escribió Engels su obra El origen de la familia, de la propiedad privada y del Estado. 
presentaban las distintas etapas intermedias, mientras que las sociedades de Europa occidental, que política y militarmente dominaban al resto del mundo en el siglo XIX, representaban la etapa más avanzada» ${ }^{30}$.

Esta concepción universalista parece deducirse también de la voz "cultura" en el Diccionario de Filosofía de FERRATER MORA. Allí se afirma: "La cultura es el mundo propio del hombre, lo cual no significa que el hombre no viva también dentro de la Naturaleza y dentro o bajo lo trascendente. Lo que caracteriza al hombre es el espiritu, y éste puede ser entendido no sólo como una espontaneidad, sino también como un conjunto de formas que fueron antes vivas $y$ espontáneas $y$ que poco a poco se transforman en estructuras rígidas, en modelos. Cultura es, como dice Scheller, humanización, pero esta humanización se refiere tanto al proceso que nos hace hombres como al hecho de que los productos culturales quedan humanizados. La historia del hombre como historia de la cultura es así el proceso de la transformación de su mundo y simultáneamente de la transformación del hombre ${ }^{31}$.

\subsection{La concepción particularista derivada del Romanticismo alemán}

El Romanticismo alemán nos legó el concepto de Volksgeist, de espíritu del pueblo, que podemos considerar como uno de los explosivos más peligrosos de los tiempos modernos ${ }^{32}$. El Volksgeist supone la conversión de la cultura en "mi" cultura. Se desprecia todo sentimiento de lo universal y se glorifican los particularismos. La Cultura ya no se remite al intento de hacer retroceder el prejuicio y la ignorancia, sino a la expresión, en su singularidad irreductible, del espíritu de cada pueblo.

El hombre es obra de su nación, y no al revés como sostenía la Ilustración. La tradición es exaltada. Está bien todo lo que existe. El va-

30 Goodenough, W. H.: "Cultura, lenguaje y sociedad», en KaHN, J. S., El concepto..., op. cit., págs. 188-189.

31 Ferrater Mora, J.: Diccionario de Filosofia, Editorial Sudamericana, 5. edición, Buenos Aires, 1965, tomo I, págs. 390-392.

${ }_{32}$ El Volksgeist ha servido de base a ideologías imperialistas y belicistas. La asunción por la Constitución de la paz como un valor nos obliga a rechazar las concepciones derivadas de esa peligrosa noción de Volksgeist. 
lor de las instituciones no lo fija ya su grado de proximidad a un modelo ideal, sino su antigüedad. Las costumbres son legítimas porque son seculares. Cuanto más antiguas, más merecen ser preservadas. Como afirma FINKIELKRAUT, "los prejuicios constituyen el tesoro cultural de cada pueblo" ${ }^{33}$. La cultura no se concibe como instrumento emancipador del hombre, sino como una instancia que lo tutela y condiciona.

Como contrapunto a la frase de Renan antes citada, podemos ilustrar la nueva concepción de cultura con una sentencia del célebre contrarrevolucionario francés DE MAISTRE. Refleja muy bien el pensamiento reaccionario que negaba los presupuestos y las consecuencias de la Filosofía de las Luces: "En el mundo, no existe el hombre. A lo largo de mi vida, he visto franceses, italianos, rusos. Sé incluso, gracias a Montesquieu, que se puede ser persa; pero en lo que se refiere al hombre, afirmo que no lo he encontrado en toda mi vida" ${ }^{34}$. Del mismo modo que se rechaza la existencia del Hombre, se rechaza la existencia de la cultura humana. Sólo se reconocen, y no sólo eso sino que se exaltan, las culturas particulares. La huella educativa de Goethe desaparece con Herder de Alemania. Las trágicas consecuencias de esta evolución no necesitan ser aquí expuestas, más aun cuando todavía hoy continúan generando muerte y destrucción en nuestro continente. Baste señalar que el genio nacional suprime a un tiempo el individuo, que queda subordinado a la comunidad a la que pertenece y encadenado a su identidad, esclavizado por la tradición, y a la humanidad a la que pulveriza en multitud de identidades culturales encerradas en si mismas cuando no en conflicto unas con otras $^{35}$.

La concepción particularista se corresponde en el campo de la antropología con la llamada escuela del "particularismo histórico", fundada por el norteamericano de origen alemán BOAS ${ }^{36}$. Éste comenzó a utilizar la palabra cultura en un sentido muy distinto al de Tylor. Con dicho término se refería al "conjunto diferenciado de costumbres, creencias e instituciones sociales que parecen caracterizar a cada so-

33 Finkielkraut, A.: La derrota..., op. cit., pág. 25.

${ }^{34}$ De Maistre, J.: Oeuvres complètes, I, Vitte, Lyon, 1884, pág. 75.

35 Finkielkraut, A.: La derrota..., op. cit., pág. 45.

36 BoAs es considerado fundador de la antropología cultural en los EE.UU. A ello no puede ser ajeno el hecho de que las tesis de Morgan hayan sido adoptadas como oficiales por la ideología comunista. KHAN, J. S.: "Introducción», El concepto..., op. cit., pág. 15. 
ciedad aislada ${ }^{37}$. La cultura seguía considerándose compuesta por las cosas de la definición de Tylor, pero las prácticas, creencias y estilo de vida de cada sociedad concreta tenian que ser examinadas como una entidad única que era distinta de cualquier otra. En vez de que las distintas sociedades tengan diferentes grados de cultura o correspondan a diferentes etapas del desarrollo cultural, cada sociedad, según Boas, tiene su "cultura propia».

\subsection{Semejanzas, diferencias y compatibilidad de las dos concepciones examinadas}

Al margen de las profundas diferencias expuestas, que son radicales pues están basadas en diferentes concepciones del hombre y de la historia, las diversas escuelas antropológicas coinciden en las siguientes ideas:

a) La cultura consiste en la memoria hereditaria no genética de la sociedad. Ello implica, en primer lugar, que "lo cultural" es concebido como lo esencialmente humano, como "la gran brecha mental entre el hombre y los animales ${ }^{38}$. $Y$ en segundo lugar, que la cultura es un hecho social: se trata de una herencia no generada por el

${ }^{37}$ Goodenough, W. H.: Cultura..., op. cit., pág. 189. Aquí Goodenough reprocha al marxismo haber adoptado las tesis de Morgan, que se corresponden según él con la uarrogante teoría etnocéntrica desarrollada por las élites imperialistas del siglo XIX». En nuestra opinión, dado que a la ideología marxista es consustancial el internacionalismo - la manipulación política que haya llevado a cabo de movimientos nacionalistas en el Tercer Mundo, sería, en todo caso lo reprobable-, resulta lógico que siga a MORGAN y no a BOAS. El error de GOODENOUGH es el brillantemente denunciado por FINKIELKRAUT: "La filosofía de la descolonización combate el etnocentrismo con los argumentos y los conceptos forjados en su lucha contra las Luces por el romanticismo alemán", esto es, con el concepto de "identidad cultural». Más adelante, al hablar de los Estados postcoloniales marxistas, con gran agudeza observa: "Los Estados postcoloniales reconciliaban, sin saberlo, a Marx con Joseph de Maistre... El propio Marx se habría ofuscado sin duda con esas nupcias contra natura con el nacionalismo". La derrota..., op. cit., págs. 68,75 y 76 . Este debate resulta del máximo interés, ya que en el tratamiento de la cuestión cultural en nuestro país se perciben los errores que FINKIELKRAUT denuncia. Los máximos defensores de los particularismos culturales, tanto en el País Vasco como en Cataluña, se autocalifican "marxistas».

${ }_{38}$ WHITE, L. A.: «El concepto de cultura» (1959), en KAHN, J. S., El concepto..., op. cit., pág. 130. En el mismo sentido, LinTon, R.: "Sin la existencia de la cultura, gracias a la cual se conservan las adquisiciones del pasado y se modelan las gene- 
individuo aislado, sino por los grupos sociales en que desarrolla su existencia ${ }^{39}$.

b) La cultura abarca un amplísimo campo de contenidos. TYLOR habla de conocimientos, creencias, arte, moral, derecho, costumbres $^{40}$. GOODENOUGH alude a formas, proposiciones, creencias, valores, reglas y valores públicos, recetas, rutinas y costumbres, sistema de costumbres ${ }^{41}$. BOAS se refiere a costumbres, creencias e instituciones sociales ${ }^{42}$. WHITE propone una lista abierta, ideas, creencias, actitudes, sentimientos, actos, pautas de conducta, costumbres, códigos, instituciones, obras de arte y formas artísticas, lenguajes, instrumentos, máquinas, utensilios, ornamentos, fetiches, conjuros... etc. ${ }^{43}$

La escuela evolucionista o universalista afirma la existencia de una sola cultura de la que las distintas sociedades participan en diferente grado. La cultura es, para ella, un proceso acumulativo ininterrumpido al que contribuye la humanidad entera. Cultura se identifica con progreso del espíritu. Frente a ella, la escuela particularista sostiene que cada sociedad tiene una cultura propia. Se pone el acento en las culturas como fenómenos que expresan el diferente modo de ser de cada pueblo. El principio de progreso fundamenta a la primera y el de pluralidad a la segunda.

Cabe preguntarse si es posible armonizar ambos principios $y$ concepciones. No nos corresponde aquí intentar encontrar una respuesta en abstracto. Analizamos la cuestión referida a un contexto determinado: la Constitución española de 1978. Y en este caso hemos de responder afirmativamente. El constituyente, al recoger ambas, nos obliga a ello. Luego veremos qué relación existe entre ambas. De momento basten estas palabras de VARGAS LLOSA que nos permiten una aproximación sugerente al tema: "Condenar 'el nacionalismo cultural' como una atrofia para la vida espiritual de un pais no significa, por su-

raciones sucesivas de acuerdo con sus patrones, el homo sapiens no sería más que un mono antropoide terrícola, ligeramente distinto en estructura y algo superior en inteligencia, pero hermano del chimpancé y del gorila». Estudio del hombre, Fondo de Cultura Económica, 9. ed., 1967, pág. 91. Del mismo autor resulta también de interés para nuestro tema la obra Cultura y personalidad, Fondo de Cultura Económica, 1965.

Lo cual es compatible con el reconocimiento de la importancia excepcional de ciertos individuos en el progreso de la cultura.

40 TYLoR, E. B.: "La ciencia...», op. cit., pág. 29.

"1 GoodenOUGH, W. H.: "Cultura...", op. cit., pág. 197.

${ }^{42}$ Goodenough, W. H.: "Cultura...", op. cit., pág. 189.

${ }^{43}$ WHITE, L. A.: «El concepto...», op. cit., pág. 154. 
puesto, desdeñar en lo más mínimo las tradiciones y modos de comportamiento nacionales o regionales... Significa únicamente reclamar, en el ámbito de la cultura, la misma libertad y el mismo pluralismo que deben reinar en lo político y en lo económico en una sociedad democrática. La vida cultural es más rica mientras es más diversa y mientras más libre e intenso es el intercambio y la rivalidad de ideas en su seno" ${ }^{44}$.

\section{LAS DOS NOCIONES DE CULTURA CONTENIDAS EN LA CONSTITUCIÓN ESPAÑOLA DE 1978}

El constituyente nos obliga a armonizar las dos concepciones de cultura. Y ello porque la Constitución española contiene las dos. Esto se observa desde el mismo Preámbulo constitucional. El párrafo cuarto alude a la protección de las "culturas" de los distintos pueblos de España y el párrafo quinto a la promoción del progreso de la "cultura". La polisemia del término cultura se pone de manifiesto con toda claridad en las expresiones preambulares citadas.

La distinción entre la "cultura" y las "culturas" que se deduce de las diferentes concepciones estudiadas - la ilustrada francesa y la romántica alemana- encuentra su reflejo en los dos párrafos del Preámbulo referidos a la Cultura. Los diferentes conceptos de "cultura" manejados por TYLOR y BOAS nos resultan de la máxima utilidad a la hora de interpretar los enunciados de los párrafos cuarto y quinto del Preámbulo de la Constitución de 1978. El significado de la locución del párrafo cuarto viene determinado por su construcción plural y posesiva, "sus culturas». Las culturas se imputan a los diferentes pueblos de España ${ }^{45}$. Fácilmente se deduce que el concepto de cultura aquí empleado es el propio

44 Vargas Llosa, M.: "El elefante y la cultura", $A B C$, Madrid, diciembre de 1981.

${ }_{45}$ La expresión preambular "pueblos de España», reiterada en el artículo 46 de la Constitución, supone una novedad en nuestro constitucionalismo. El origen del sintagma lo encontramos en el lenguaje antropológico: "pueblos hispánicos», "pueblos de la Península lbérica", "pueblos de España". Así, desde el clásico BaroJA, J. C., Los pueblos de España, Istmo, Madrid, 1963, hasta el reciente, Prat, Martinez, Contreras, Moreno (eds.), Antropología de los pueblos de España, Taurus, Madrid, 1991. De su recepción constitucional se derivan una serie de consecuencias en materia cultural. Como señala PRIETo de Pedro, "por el interior de la noción de 'pueblos de España' corre savia cultural», Prieto de Pedro, J., Cultura..., op. cit., pág. 123. En el Preámbulo constitucional la cultura no es la única cualidad imputada a los pueblos de España, sino una más. Los sustantivos "tradiciones", "lenguas" e "instituciones" acompañan al término "culturas". Sin embargo, parece que éste último es el concepto capital y que los demás sustantivos se limitan a complemen- 
de la escuela particularista. Por el contrario, el párrafo quinto, al proclamar como voluntad de la nación "el progreso de la cultura", parece corresponderse mejor con una concepción universalista ${ }^{46}$. La introducción de la idea de progreso presenta, además, ecos ilustrados evidentes ${ }^{47}$.

tarlo. Y esto por varias razones: a) El término "culturas" aparece en primer lugar, lo cual puede atribuirse a su carácter principal. b) El significado cultural de la palabra "lenguas" es patente, puesto que el artículo 3.3 del texto articulado las califica de "patrimonio cultural". c) El término tradiciones, situado entre los dos anteriores, ha de compartir su significado. Dicha interpretación se ve fortalecida por el empleo de la conjunción copulativa "y", "culturas y tradiciones", la cual en otro caso no era necesaria. Respecto al último término del enunciado preambular, observamos que la noción de "instituciones" es también utilizada por la Antropología, pero aquí su significación cultural es más problemática. Parece prudente mantener que nos encontramos ante una noción abierta y genérica, cuyas manifestaciones -políticas, jurídicas, sociales, culturales- dependerán del bagaje de cada pueblo en cuestión. Así, a título de ejemplo, unos tendrán instituciones jurídicas propias (derechos forales) y otros no. La noción sirve, en todo caso, para alejar las visiones exclusivamente espiritualistas de los pueblos que la idea del Volksgeist pudiera originar. A favor de una interpretación cultural de la expresión "pueblos de España" juega también la proyección de la misma en el articulado constitucional. Así el artículo 46 habla del "patrimonio histórico, cultural y artístico» de los pueblos de España. El reconocimiento constitucional de los pueblos de España, efectuado por el Preámbulo y el artículo 46 del texto articulado, tiene por efecto atribuir al Estado la protección de los patrimonios culturales de los mismos. Distinto significado tiene la mención preambular del "pueblo español». En este caso se trata de una noción dotada de una indudable carga politica, puesto que el pueblo español es el poder constituyente. Asi se deduce del propio Preámbulo según el cual el pueblo español ratifica la Constitución y de numerosos preceptos del articulado que concretan la genérica declaración del artículo 1.2: "La soberanía nacional reside en el pueblo español». No hace falta insistir, ni siquiera recordar, que el pueblo español es el único soberano. Si como poder constituyente el concepto de pueblo es de origen revolucionario francés, como noción cultural es fruto del romanticismo alemán.

46 Prieto de Pedro, J., pone también de manifiesto la polisemia de la voz cultura en el Preámbulo constitucional. En el párrafo cuarto afirma que se contiene la "noción étnica de cultura" y en el quinto la "noción general de cultura". Cultura..., op. cit., pág. 51. Dedica las páginas 51 a 57 a explicar la noción étnica. A favor de esta expresión alega, además de numerosos textos de la UNESCO e incluso constituciones de otros países, el ya clásico trabajo de B. AzkIN, Estado y Nación, en el cual se aboga por despojar al adjetivo étnico de sus connotaciones biológicas o primitivas: "El adjetivo étnico, tal como se usa hoy día, indica aquellas características, cualesquiera que puedan ser, que, al prevalecer dentro del grupo y distinguirlo de los demás, nos inclinan a considerarlo un pueblo aparte. Para el hombre de la calle un pueblo es el equivalente de lo que el informado llama un grupo étnico". Fondo de Cultura Económica, México, 1968, pág. 34.

47 Para comprender la relevancia del concepto de "progreso" como elemento caracterizador del pensamiento ilustrado, CONDORCET, Bosquejo de un cuadro histórico de los progresos del espíritu humano, Edición preparada por TORRES DEL Moral, A., Editora Nacional, Madrid, 1980. 
Advertimos asi que la noción constitucional de "cultura» tal y como viene anticipada en el Preámbulo constitucional es una noción compleja. La complejidad de la misma viene determinada por el valor polisémico del término. $Y$ polisemia, permítasenos el juego de palabras, es sinónimo de ambigüedad. Ambigüedad que, una vez más, encuentra su explicación en las circunstancias históricas en que se gesta nuestro texto constitucional.

El constitucionalismo es hijo de la llustración y los ecos de las Luces se perciben en el texto preambular. La fórmula uprogreso de la cultura" nos remite a CONDORCET. De esto cabría deducir que la noción constitucional de cultura coincide con la de RENAN, el último GOETHE, TYLOR, etc. Parece absurdo que la Constitución, fruto del racionalismo moderno, recoja el concepto de cultura propio de la reacción francesa o del irracionalismo alemán, de HERDER o DE MAISTRE ${ }^{48}$.

La introducción en el Preámbulo del concepto de "culturas" atribuidas a los distintos pueblos de España se explica como reacción frente al afán uniformizador de la dictadura ${ }^{49}$. Dicha concepción particularista de la cultura aparece junto a su contrincante histórico: la noción ilustrada. Esta última es plenamente coherente con la ideologia que inspira el texto preambular, que es la que informa al movimiento constitucional: los ideales de la llustración. La noción constitucional de cul-

48 Ésa es, sin embargo y paradójicamente, la concepción que se desprende de los textos y documentos de la UNESCO que continuamente se refieren a las "identidades culturales". Sobre este tema, destacando los aspectos positivos, PRIETO DE PEDRO, J., "La posición de la UNESCO", en Cultura..., op. cit., págs. 91-96. Muy crítico, FInKIELKRAUT, A., "El doble lenguaje de la UNESCO», en La derrota..., op. cit., págs. 84-90. Con la gran conversión de la cultura en identidad cultural -escribe FiNKIELKRAUT- la UNESCO entiende por cultura "exactamente lo mismo que el pensamiento de las Luces denomina la incultura o el prejuicio", pág. 86.

49 El hecho de que los nacionalismos centralizadores generan nacionalismos perífericos ha sido ya suficientemente estudiado. Lo que nos interesa destacar, en orden a nuestro tema, es que a la noción particularista de cultura propia de la dictadura, las fuerzas progresistas, en su mayoría, no oponen la concepción ilustrada. No se arguye que por encima de la cultura española está la cultura humana, como diría Renan, sino que a la concepción particularista de cultura española se oponen visiones más reduccionistas aún. El particularismo se acentúa hasta el absurdo. Por más acusadas que sean las diferencias y más opuestos los principios políticos que en otros ámbitos propugnen, los ideólogos de la raza española, propagandistas de la cultura nacional-católica y los teóricos de los movimientos regionalistas o nacionalistas comparten un concepto de cultura. Se alimentan de una concepción ensimismada sobre la diferencia cultural, que se sostiene en un fatuo orgullo de lo propio que niega al otro. Unos y otros perciben las culturas como totalidades englobantes. 
tura que el Preámbulo contiene se compone, pues, de las dos concepciones históricas y opuestas que de "cultura" han existido. En este texto coexisten pacificamente, uno junto a otro, enemigos seculares. El análisis de la proyección de ambas nociones en el articulado del texto constitucional nos permitirá ver cómo esta coexistencia, que conceptualmente parece tan problemática, es posible.

El examen de la proyección en el texto constitucional de los principios preambulares de "protección de las culturas" y de "progreso de la cultura" nos permitirá determinar la relación existente entre los párrafos cuarto y quinto del Preámbulo constitucional. Hemos de ver, pues, cómo se reflejan en el articulado constitucional los fundamentos del Estado de Cultura: el pluralismo y el progreso cultural.

\section{EL PLURALISMO CULTURAL EN LA CONSTITUCIÓN}

No hay pluralismo - ni progreso- sin libertad, así que podemos afirmar que la libertad es el principio fundamental de nuestra "constitución cultural».

\subsection{La libertad cultural como presupuesto}

Como presupuesto del pluralismo al que alude el Preámbulo, la Constitución española, como Constitución de un Estado de Cultura, reconoce un gran repertorio de libertades. Todas ellas tienen como fundamento el principio "del libre desarrollo de la personalidad" que la propia constitución recoge en el artículo 10.

Siguiendo a PRIETO, podemos establecer la siguiente tipología ${ }^{50}$ :

a) Libertades de creación cultural: derechos a la libre creación literaria, artística, científica y técnica, y derechos de protección sobre dichas creaciones (artículo 20.1.b).

b) Libertades de comunicación cultural: derecho genérico a la libre transmisión de la cultura, libertad de enseñanza, libertad de cátedra (artículos 20.1.c y 27.1).

50 Prieto de Pedro, J.: Cultura..., op. cit., pág. 225. 
c) Libertades de emprendimiento e institucionalización cultural que garantizan la pluralidad de iniciativas en relación a la cultura impidiendo el monopolio de iure de los poderes públi$\cos$ (artículos $22,27.5$ y 34 ).

\subsection{Manifestaciones del pluralismo}

La Constitución española de 1978 contiene un amplio repertorio de garantías de la pluralidad cultural de los diferentes grupos en los que los ciudadanos españoles se mueven. El presupuesto sobre el que descansan todos ellos es la consideración del pluralismo cultural como un valor.

El mayor desarrollo de este principio se encuentra en la garantía del pluralismo cultural de los pueblos de España. El pluralismo se concreta, entonces, en un sistema de autonomías territoriales dotadas de amplísimas facultades de autogobierno en materia cultural. Tal es el sentido del reconocimiento del derecho a la autonomía por el artículo 2 y su desarrollo en el Título VIII. Especialmente enfática es también la declaración del artículo 3: "La riqueza de las distintas modalidades lingüísticas de España es un patrimonio cultural que será objeto de especial respeto y protección". Igualmente se proyecta el pluralismo en el artículo 46.

Además, la Constitución garantiza el pluralismo cultural en instituciones concretas: centros de enseñanza y medios de comunicación:

a) El artículo 27 garantiza el pluralismo educativo. En sus apartados 1 y 6 el pluralismo ad extra y en sus apartados 5 y 7 ad intra ${ }^{51}$.

b) El artículo 20.3 en relación con los medios de comunicación social del Estado establece que la ley habrá de garantizar "el acceso a dichos medios de los grupos sociales y políticos significativos, respetando el pluralismo de la sociedad y de las diversas lenguas de España».

Por lo que se refiere al Título VIII, allí se establece un reparto competencial de algunas materias singulares relacionadas con la cultura en

51 Fernández-Miranda, A.: "Comentario al artículo 27", en Comentarios a las Leyes Políticas, Edersa, Madrid, 1984, tomo III. Prieto de Pedro, J.: “Consideraciones sobre...", op. cit., págs. 526-527. 
virtud del cual lo que es competencia del Estado no lo es de la Comunidad Autónoma y viceversa. Asi, en materia de educación (149.1.27), investigación (148.1.17 y 149.1.15), patrimonio cultural (148.1.15 y 149.1.28), medios de comunicación social (149.1.30), propiedad intelectual (149.1.9). Estas competencias tienen por objeto no la cultura en sentido estricto, sino sus instrumentos institucionales de expresión ${ }^{52}$. El objetivo que persiguen es que el Estado configure un minimum de igualdad jurídico-institucional para los medios e instrumentos de creación, conservación y transmisión de la cultura, a través de los cuales los ciudadanos acceden a ella. En modo alguno esos preceptos niegan el pluralismo.

El pluralismo, como principio constitucional aplicado a la cultura, exige que, sea cual sea la cultura dominante en cada parte del territorio nacional, todas y cada una de ellas deben ser permeables a la influencia de las otras, asi como a la de cualquiera de otra área del mundo. Lo contrario supone la petrificación cultural. Y petrificación es lo contrario de progreso. Una interpretación excluyente del pluralismo, como afirmación ensimismada de una uidentidad cultural» concreta, no cabe en la Constitución. Tan fundamental para nuestra "constitución cultural» es el principio de progreso como el de pluralismo. El segundo ha de ser interpretado en función del primero. De hecho, como veremos después, encuentra en él su límite.

\subsection{Pluralismo y unidad: Los artículos 148.1 .17 y 149.2 de la Constitución}

Vistas las manifestaciones del principio pluralista, debemos preguntarnos ahora cómo se vertebran en la unidad estatal ${ }^{53}$. Porque la unidad, como acertadamente señala GONZÁLEZ ENCINAR, es una cualidad inherente a cualquier Estado ${ }^{54}$.

El análisis ha de partir de los siguientes presupuestos:

52 Prieto de Pedro, J.: Cultura..., op. cit., pág. 263. Lo contrario supondría una visión fragmentaria de la Cultura que seria incompatible con la concepción totalizadora de la misma que subyace en los preceptos que estudiamos en el siguiente epígrafe.

53 Prieto de Pedro, J.: "Unidad y pluralismo cultural en el Estado autonómico", en Documentación Administrativa, n. ${ }^{\circ} 232-233,1993$, págs. 33-56.

54 González Encinar, J. J.: El Estado unitario federal, Tecnos, Madrid, 1985. 
a) Ni la doctrina ni la jurisprudencia constitucional emplean la expresión "unidad cultural". EI TC en una de sus primeras sentencias se refirió a la uunidad política, jurídica, económica y social de España". Posteriormente ha hablado de "unidad fiscal", "unidad de mercado", pero nunca de unidad cultural. Por lo que a la doctrina se refiere, cabe destacar la afirmación del principio de comunidad cultural por TORRES DEL MORAL: "La unidad territorial es el soporte de una comunidad de culturas $)^{55}$. La mayoría de los autores guarda silencio sobre el tema.

b) La cultura, en su totalidad, es competencia del Estado, en virtud del artículo 149.2 de la Constitución, y competencia de las Comunidades Autónomas, con base en el artículo 148.1.17. No nos encontramos ni ante una competencia exclusiva ni ante una materia repartible, sino ante un asunto confiado de forma paralela y simultánea al Estado y a las Comunidades Autónomas ${ }^{56}$. Ello no ocurre con ninguna otra materia objeto de regulación constitucional. Una mirada a los Diarios de Sesiones nos muestra que esta dualidad competencial fue buscada expresamente. Así el senador DE LA CIERVA afirmó que "la cultura es una realidad profunda $y$ trascendente cuyo fomento no puede atribuirse en exclusividad al Estado ni a las Comunidades Autónomas ${ }^{57}$.

Lo anterior nos permite afirmar que aunque ni la doctrina ni la jurisprudencia hablen de unidad al tratar de la cultura, dicha unidad estuvo presente en la mente del legislador constituyente. La lectura de los preceptos contenidos en los artículos 148 y 149 nos pone de manifiesto que el constituyente concibió la cultura como una totalidad, como una unidad no susceptible de troceamiento competencial. Subyace la concepción de la cultura más que como una materia como un valor. Valor que todo el Estado, tanto a través de sus órganos centrales como territoriales, debe proteger y perseguir ${ }^{58}$.

A las Comunidades Autónomas el artículo 148.1.17 les permite asumir una competencia global de "fomento de la cultura". $Y$ nótese

55 Torres del Moral, A.: Principios..., op. cit., vol. II, pág. 301.

${ }_{56}$ Prieto de Pedro, J.: Cultura..., op. cit., pág. 254. Torres del Moral, A.: Principios..., op. cit., vol. I, pág. 605. 2623-2624.

57 Diario de sesiones del Senado, $n .^{\circ} 54,13$ de septiembre de 1978, págs.

58 Torres del Moräl, A.: Principios..., op. cit., vol. I, pág. 87. 
que se dice de la cultura, en singular. Se halla, pues, aquí proyectado, en primer lugar, el enunciado del párrafo quinto del Preámbulo, y no sola o principalmente el del cuarto como pudiera pensarse por la mención de las Comunidades Autónomas. El pluralismo otorga competencias culturales a las distintas entidades político-territoriales en que se articula la organización del Estado. Pero esas competencias versan sobre la cultura en sentido global, o, como antes dijimos, en sentido ilustrado y no sólo en sentido particularista. Al mismo tiempo y en el mismo sentido, el artículo 149.2 encomienda al Estado "el servicio de la cultura $\|^{59}$. y lo hace en unos términos que no se repiten en ningún otro lugar de la Constitución: el servicio de la cultura es uun deber y atribución esencial» del Estado ${ }^{60}$.

Así parece entenderlo también el Tribunal Constitucional. En su Sentencia 49/84 se ocupa del tema y la doctrina aquí sentada se invocará después en múltiples ocasiones: «... Una reflexión sobre la vida cultural, lleva a la conclusión de que la cultura es algo de la competencia propia e institucional tanto del Estado como de las Comunidades Autónomas, y aún podríamos añadir de otras comunidades, pues allí donde vive una comunidad hay una manifestación cultural respecto de las que las estructuras públicas representativas pueden ostentar competencias, dentro de lo que, entendido en un sentido no necesariamente técnico-administrativo, puede comprenderse dentro de "fomento de la culturan. Ésta es la razón a la que obedece el artículo $149.2 \mathrm{CE}$,

59 Prieto de Pedro, J., considera que el juego de estos dos preceptos permite respectivamente a las Comunidades Autónomas proteger y promover sus "culturas" locales, y al poder central defender la "cultura española». Cultura..., op. cit., pág. 260.

60 Cosa distinta es que el precepto sea tomado en serio por los poderes que han de aplicarlo. El examen de la partida de los Presupuestos Generales del Estado destinada al Ministerio de Cultura no nos llevaría a pensar que, a diferencia de otros, éste tiene encomendada la gestión de un "deber y atribución esencial del Estado". Sobre este tema, Torres del Moral, A., resalta cómo en 1981 dos ciudades alemanas, Francfurt y Hamburgo, gastaron en cultura unos 16.000 millones de pesetas. España ese año dedicó a la cultura 13.000 millones. Comentario al artículo 44..., op. cit, pág. 207. Véanse también los artículos publicados en El País, días 2 de junio de 1981 y ss., sobre "La financiación de la vida cultural». En los últimos años la situación ha mejorado, aunque no faltan fuerzas políticas que, en el más absoluto desconocimiento de este deber estatal, propugnan no ya un aumento del presupuesto destinado a Cultura, sino simplemente la supresión del Ministerio de Cultura. ¿En qué quedaría entonces el art. 149.2? Por supuesto que el servicio de la cultura es mucho más que un Ministerio, pero la estructura jurídico-administrativa que éste proporciona parece imprescindible para la realización de una política efectiva de fomento de la cultura. 
en el que después de reconocer la competencia autonómica afirma una competencia estatal, poniendo el acento en el servicio de la cultura como deber y atribución esencial. Hay, en fin, una competencia estatal y una competencia autonómica en el sentido de que más que un reparto competencial vertical, lo que se produce es una concurrencia de competencias ordenada a la preservación y estímulo de los valores culturales propios del cuerpo social desde la instancia pública correspondiente".

Las afirmaciones del Tribunal no dejan de ser oportunas y ciertas. Sin embargo, pienso que hay que destacar también que de la literalidad de los preceptos que analizamos, en conexión con el párrafo quinto del Preámbulo y no solamente del cuarto, se deduce también una obligación común de velar por la cultura entendida como cultura universal. De hecho el propio PRIETO reconoce que la voz cultura en los preceptos que estudiamos cubre los contenidos de las dos nociones de cultura existentes, que él denomina étnica y general y nosotros particularista e ilustrada o universalista ${ }^{61}$. De esa forma, tanto el párrafo cuarto del Preámbulo como el párrafo quinto se encuentran aquí reflejados. En cualquiera de los casos, la función que dichos preceptos cumplen es conjugar el principio pluralista con el de unidad de la Cultura.

\section{EL PROGRESO DE LA CULTURA}

\subsection{Manifestaciones generales del principio}

Junto a la protección del pluralismo cultural (párrafo cuarto del Preámbulo), la promoción del progreso de la cultura (párrafo quinto) es el otro principio fundamentador de nuestra "constitución cultural". En realidad no es exagerado decir que la asunción del progreso de la cultura como fin estatal ${ }^{62}$ es lo que diferencia a un Estado de Cultura de otro que no lo es. Este principio exige una acción positiva del Estado para hacer accesibles a todos los ciudadanos los bienes culturales. A lo

61 Prieto de Pedro, J.: Cultura..., op. cit., pág. 264.

${ }_{62}$ Sobre los fines del Estado, JELL.INEK, G., Teoría general del Estado, traducción de Fernando de los Ríos, Albatros, Buenos Aires, 1954, págs. 169 y ss. 
largo del texto constitucional encontramos numerosos preceptos en que se atribuyen a los poderes públicos tareas en orden al desarrollo de la Cultura:

a) Según el artículo 44.1, deben tutelar y promover el acceso a la cultura.

b) De los artículos 27.4 y 9 se desprende que han de garantizar la gratuidad de la enseñanza. A los poderes públicos compete la programación general de la enseñanza, con la participación de los sectores afectados, el principio democrático modula así el cultural, y la creación de centros docentes (art. 27.5), asi como la vigilancia de todo el sistema educativo para garantizar que se cumplen las leyes (art. 27.8).

c) El Estado, en virtud del artículo 44.2, ha de promover el desarrollo de la investigación y la ciencia en beneficio del interés general.

d) El artículo 46 atribuye a los poderes públicos el deber de garantizar la conservación y promover el enriquecimiento del patrimonio cultural.

e) Otros muchos artículos contienen también obligaciones específicas del Estado en relación con lo cultural: artículos 25 (derecho de acceso a la cultura de las personas condenadas a penas privativas de libertad), 43.3 (sobre educación sanitaria, educación física, deporte y ocio), 50 (sobre los servicios culturales para la tercera edad) y 51 (sobre la formación y educación de consumidores $y$ usuarios).

\subsection{El derecho a la cultura. El artículo 44 de la Constitución}

El artículo 44 de la Constitución de 1978 establece: "Los poderes públicos promoverán y tutelarán el acceso a la cultura, a la que todos tienen derecho". Disposiciones de este tenor son muy escasas en el Derecho constitucional comparado. Lo corriente en los textos constitucionales de nuestro entorno es emplear la expresión "derechos culturales". El antecedente de nuestro artículo 44 lo encontramos en la Constitución portuguesa de 1976, que dispone en su artículo 73.1: "Todos tienen derecho a la educación y a la culturan. 
De hecho, en la literatura jurídica encontramos también la expresión "derechos culturales" como una categoría dentro de la tipología de los derechos fundamentales ${ }^{63}$.

Como causas que explican la reticencia a reconocer el «derecho a la cultura" cabe señalar las siguientes:

a) La inseguridad del legislador ante la noción misma de cultura.

b) El temor a que de la cultura se derive una incontrolable demanda social de prestaciones.

c) Restos de un pudoroso recelo, heredado del viejo Estado liberal, a considerar la cultura como objeto de prestación de los poderes públicos.

Los constituyentes españoles y portugueses dan un paso decisivo al consolidar la cultura como un derecho autónomo, en concreto como un derecho de prestación ${ }^{64}$.

En el caso español, la ubicación constitucional del «derecho a la cultura» en el capítulo tercero del Título I, "De los principios rectores de la política social y económican, implica que las garantías del mismo son las previstas en el artículo 53.3 de la Constitución: vinculación finalista de la actividad de los poderes públicos, aunque sin posibilidad de ser exigidos de forma inmediata ante los Jueces y Tribunales.

Una concreta especificación del derecho a la cultura, el derecho a la educación, que también se configura como derecho de prestación, se halla en capítulo aparte. Ello obedece a la voluntad del constituyente de otorgar al derecho a la educación las máximas garantías constitucionales. El artículo 27 goza de la máxima protección que ofrece el artículo 53.2. "A pesar de una historia no excesivamente brillante en nuestros textos constitucionales -escribe LÓPEZ GUERRA- y en la práctica gubernamental, el derecho a la educación básica se configura hoy como un derecho subjetivo accionable inmediatamente, siendo el

63 Pur, F.: “Ensayo de definición de los derechos culturales", en Anuario de Derechos Humanos, n. 5, 1988-89, págs. 202 y ss. Sobre los derechos de prestación, Fernández Rodríguez, T. R.: "Los derechos fundamentales y la acción de los poderes públicos», Revista de Derecho Político, UNED, 1982, n. 15.

64 «El derecho a la cultura es un derecho social en todo el sentido de la expresión. Quiérese decir con ello, no sólo que la cultura sea un bien social, sino que además tiene una proyección netamente social». GÁlVEZ, J., "Comentario...", op. cit., pág. 803. 
Estado responsable de su satisfacción, en forma directa (centros públicos) o indirecta (subvenciones a centros privados), según la modalidad que la ley parlamentaria escoja» ${ }^{65}$.

FOSSAS ha señalado que el derecho a la cultura es el centro de gravedad de la Constitución española ${ }^{66}$. Puede ser exagerada la expresión, pero lo cierto es que el artículo 44 marca un hito en nuestro constitucionalismo. La visión que el constitucionalismo había tenido del fenómeno cultural había sido siempre fragmentaria. Lo cultural aparecia de forma dispersa, nunca globalmente considerado. Ahora se configura como una totalidad y como un medio indispensable para lograr el establecimiento de una sociedad democrática avanzada, objetivo fundamental del constituyente. El progreso de la cultura al que expresamente alude el Preámbulo se encuentra implícito en la fórmula sociedad democrática avanzada. Pero también podemos decir que la sociedad democrática avanzada está incluida en la idea de progreso de la cultura, una vez que damos a este concepto un significado omnicomprensivo e identificamos progreso de la cultura con progreso del espíritu o de la razón, y que tomamos a la democracia y al Estado de Derecho como elementos culturales de una sociedad dada.

El artículo 44 permite, pues, una visión plena, totalizadora, global, del hecho cultural. Como señala TORRES DEL MORAL, el artículo 44 contiene uun concepto complejo y rico de cultura como cultivo del hombre en su más variada exigencia, como desarrollo de todas sus aptitudes, de todas sus capacidades; es la paideia de los griegos, la humanitas de los romanos, la civilitas del hombre medieval ${ }^{67}$. En el mismo sentido, escribe PRIETO, "en el artículo 44 es donde la mención a la cultura despliega toda su plenitud semántica: en tanto condensa la dimensión público-subjetiva de los ciudadanos ante los poderes públicos en las posibles exigencias de acceso a las manifestaciones de la cultura, cumple una función globalizadora, de síntesis, de la totalidad de los contenidos comprendidos en la noción étnica de cultura, como derecho a la diferencia, y en la noción general de cultura, como facultad de acceder a los bienes del espíritu que esta noción incluye ${ }^{68}$.

${ }^{65}$ López Guerra, L.: "Las dimensiones del Estado social de Derecho», en Sistema, n. ${ }^{\circ} 38-39,1980$, pág. 181.

${ }_{66}$ Fossas, E.: Regions i sector cultural en Europa..., op. cit., pág. 29.

${ }^{67}$ ToRres del Moral: "Comentario al artículo 44...", op. cit., pág. 210.

68 Prieto de Pedro, J.: Cultura..., op. cit., pág. 281. 
De la literalidad del precepto se desprende que el objeto del derecho constitucional recogido en el artículo 44 no es tanto la cultura como el acceso a ella ${ }^{69}$. Como advierte TORRES DEL MORAL, el derecho a la cultura es el derecho a los medios que faciliten su acceso ${ }^{70}, y$ como, por una parte, esos medios no son de producción y conservación espontánea, y por otra, dicho acceso no es abierto y libre, igualmente natural y económicamente factible, sino que queda reservado a unos pocos, el derecho a la cultura se convierte en el derecho a un servicio público. Enlazamos así con el tema de la función cultural del Estado.

\subsection{La función cultural del Estado}

Como señala GÁLVEZ, el acceso a la cultura al que todos tienen derecho tendrá que promoverse fundamentalmente partiendo de la organización y puesta en funcionamiento de los «servicios públicos culturales" ${ }^{71}$.

La mera garantía de la libertad cultural no asegura el acceso de todos a la cultura. Los poderes públicos han de adoptar medidas positivas de desarrollo, a fin de hacer accesibles a todos los bienes culturales. ¿Quién garantizaría la conservación del patrimonio cultural si el poder público no asumiera dicha función? ¿Estaría igualmente asegurada la educación de todos los ciudadanos en condiciones de igualdad, si el Estado no la concibiera como un servicio público?

La aparición de los "servicios públicos culturales" es la lógica consecuencia de haber asumido el Estado como función el desarrollo de la cultura, el progreso de la cultura, según la expresión preambular. $Y$ haberlo asumido no como una función más, sino como "deber y atribución esencial» según la fórmula empleada por el artículo 149.2 .

La redacción del artículo 149.2 no es hiperbólica. Es la constatación del hecho real de que como dijo ALZAGA en el debate constitu-

69 En el mismo sentido, GÁLVEZ, J.: "Comentario al artículo 44", en Comentarios a la Constitución (Garrido Falla, F., dir.), Civitas, 2. ed, Madrid, 1985, pág. 803.

70 Torres del Moral, A.: "Comentario...", op. cit., pág. 214.

$"$ Gálvez, J.: "Comentario...", op. cit., pág. 804. 
yente, recordando palabras de MITTERRAND, uhoy para cambiar la sociedad no es necesario tomar el cuartel de invierno, basta con tomar la escuelan ${ }^{72}$.

WEBER definió al Estado por ser titular éste del «monopolio de la violencia física legítima " ${ }^{73}$. GELLNER, con gran agudeza, consideró aún más importante el monopolio de la educación: "En la base del orden social moderno no está ya el verdugo, sino el profesor. El símbolo y principal herramienta del poder del Estado no es ya la guillotina, sino el (y nunca mejor dicho) doctorat d'état. Actualmente es más importante el monopolio de la legítima educación que el de la legítima violencia ${ }^{74}$.

Por otra parte, por la relación del artículo 44 con los ya estudiados 148 y 149, resulta especialmente acertada la consideración de los "poderes públicos" como titulares de la obligación correlativa al derecho a la cultura ${ }^{75}$. La función cultural corresponde tanto al Estado como a las Comunidades Autónomas.

Como conclusión de todo lo expuesto podemos afirmar que el servicio público de la cultura constituye uno de los rasgos definidores del Estado actual; que el estudio de la Constitución cultural de España reviste interés para el jurista y que calificar a España como Estado de Cultura no es una afirmación gratuita.

El interés del tema aumenta cuando nos planteamos el hipotético conflicto entre las dos nociones de cultura. El jurista ha de dar una respuesta en términos de derecho a los problemas de esta naturaleza que puedan surgir. A ello dedicamos los últimos apartados de esta exposición.

72 Diario de Sesiones del Senado, 27 de septiembre de 1978, pág. 3009. Naturalmente, el democristiano Alzaga reproducía las palabras del socialista Mitterrand para criticarlas.

73 WeBeR, M.: La Política como profesión, traducción de J. Abellán, EspasaCalpe, Madrid, 1992, pág. 94.

74 GeLLNer, E.: Naciones y nacionalismo, Alianza, Madrid, 1988, pág. 57.

75 Gálvez, J.: "Comentario...", op. cit., pág. 804. Prieto de Pedro, J.: Cultura..., op. cit., pág. 281-282. Sobre la función cultural de los poderes públicos se ha ocupado la doctrina francesa. MESNARD, A. H.: Droit et politique de la culture, PUF, París, 1990. CARON: L'Etat et la culture, Economica, París, 1989. FumAROLI, M.: L'Etat culturel. Essay sur une religion moderne, Ed. Fallois, París, 1991. 


\section{8. ¿ES NUESTRA CONSTITUCIÓN CULTURAL RELATIVISTA?}

Los derechos fundamentales son parte de la cultura ${ }^{76}$. PIzzorusso engloba las garantías de los derechos en la "constitución cultural»". Para LUCAS VERDÚ, el Estado de Derecho es un principio de cultura ${ }^{78}$.

La conexión entre el principio democrático y el principio de Estado de Cultura se encuentra perfectamente realizada en el artículo 3 de la Constitución mejicana. Allí se establece el derecho a una educación democrática, "considerando a la democracia no solamente como una estructura jurídica y un régimen político, sino como un sistema de vida fundado en el constante mejoramiento económico, social y cultural del pueblo".

En nuestra Constitución el principio o elemento cultural es inescindible de los demás elementos configuradores del Estado. El progreso de la cultura no puede desligarse de la lucha por consolidar un Estado de Derecho y una sociedad democrática avanzada. Difícilmente se perfeccionará la democracia si no se produce un notable progreso de la cultura. $Y$ al mismo tiempo el progreso de la cultura exige el esfuerzo y la participación de todos, es decir, la profundización de la democracia. El Estado de Cultura impregna, en consecuencia, a todas las demás notas definitorias del Estado y al mismo tiempo se encuentra modulado por ellas.

PRIETO DE PEDRO lo ha expuesto brillantemente. EI Estado de Cultura viene a completar, no a negar, el Estado social y democrático de Derecho: "La profundización de la democracia - recordemos que el Preámbulo de nuestra Constitución plantea como meta final alcanzar una sociedad democrática avanzada- más allá de garantizar la participación de todos los ciudadanos implica perseguir el objetivo cualitativo de hacer posible que esa participación sea más plena, más idónea, de forma especial mediante el reforzamiento de las garantías jurídicas de las instituciones que inciden en la formación y en el desarrollo de la personalidad de los ciudadanos, así como de los grupos en los que de-

76 Prieto de Pedro, J.: Cultura..., op. cit., pág. 282. Peces Barba, G.: Curso de Derechos fundamentales, Eudema, Madrid, 1991, págs. 99 y ss. "Los derechos humanos son una realidad cultural de la vida social", pág. 178.

217.

77 Pizzonusso, A.: Lecciones de Derecho constitucional..., op. cit., págs. 193-

78 Lucas Verdú, P.: La lucha por el Estado de Derecho, Bolonia, 1975, pág. 17. Curso..., op. cit., vol. IV, pág. 356. 
senvuelven su existencia, es decir, de los institutos que aseguran la libertad de la cultura, su multiplicidad, su progreso y el igual acceso de todos los ciudadanos a ella. Si el Estado social Ilamó la atención sobre las garantías de lo económico-social en la persecución de ese objetivo de profundización de la democracia, el Estado de Cultura enfatiza la importancia cualitativa de lo cultural en su consecución. El Estado de Cultura no niega, pues, la aportación de las cláusulas de Estado democrático, Estado social y Estado de Derecho, sino que pretende situar en el corazón de ellas el valor de la cultura como radical principio humanizador de la acción del Estadon" ${ }^{79}$.

Esta implicación recíproca entre los elementos jurídico, social, democrático y cultural de nuestro sistema constitucional se refleja en el artículo 27.2 de la Constitución: «La educación tendrá por objeto el pleno desarrollo de la personalidad humana en el respeto a los principios democráticos de convivencia y a los derechos $y$ deberes fundamentales ${ }^{80}$. Este precepto recoge el "principio de enculturación democrática» ${ }^{81}$. Principio que concibe la educación como instrumento emancipador y no como medio de sumisión del individuo a «identidades culturales". Principio, por tanto, ilustrado, pues el libre desarrollo de la personalidad implica también libertad frente a los prejuicios y tradiciones que caracterizan la noción de cultura propia de los particula-

79 Prieto de Pedro, J.: Cultura..., op. cit., pág. 223.

so Este artículo es casi coincidente con la primera parte del artículo 26.2 de la Declaración Universal de Derechos Humanos: «La educación tendrá por objeto el pleno desarrollo de la personalidad humana y el fortalecimiento del respeto a los derechos humanos y a las libertades fundamentales". GARRIDO FaLLA ha señalado que el artículo 27.2 "significa obviamente el establecimiento de límites al pluralismo ideológico en materia educativa, y por consiguiente, al neutralismo absoluto, pues, por ejemplo, resultaría contraria a la Constitución una enseñanza de carácter antidemocrático o defensora del racismo o la esclavitud. Se trata, por lo demás, de límites válidos tanto para la enseñanza en centros públicos, como privados". "Comentario al artículo 27 ", en Comentarios a la Constitución..., op. cit., pág. 550. Compárese el artículo 27 con su antecedente inmediato de la Ley General de Educación de 4 de agosto de 1970, que establecía como fines de la Educación, entre otros, "la preparación para el ejercicio responsable de la libertad, inspirado en el concepto cristiano de la vida y en la tradición y cultura patrias... todo ello de conformidad con lo establecido en los Principios del Movimiento Nacional". Y este articulo se observaba. Véase, a título de ejemplo, la STS de 23 de enero de 1974 (Aranzadi, Ref. 37). Merece la pena traer a colación estas palabras escritas por MADARIAGA, S. DE, hace ya sesenta años: "La educación y la instrucción de nuestro pueblo, dos funciones distintas, aunque inseparables, han de proponerse: dar la conciencia de España, de la Humanidad y de sí mismos a todos los españoles». Anarquía y jerarquía, Aguilar, 3. ${ }^{2}$ ed, Madrid, 1970, pág. 209.

81 Prieto de Pedro, J.: Cultura..., op. cit., pág. 282. 
rismos. Educación, libertad y derechos fundamentales son términos inseparables de la noción de cultura.

Las consecuencias que se derivan del artículo 27.2 son, en lo que a nuestro tema se refiere, fundamentales. El interrogante tantas veces suscitado y nunca satisfactoriamente resuelto: la aparente incompatibilidad de las dos nociones de cultura contenidas en el Preámbulo constitucional, encuentra aquí la respuesta. Este precepto, además de imponer un deber positivo a los poderes públicos en relación con los servicios culturales formativos de la personalidad, les impone el deber de impedir la promoción de aquellas prácticas y manifestaciones, supuestamente culturales, contrarias a los derechos humanos o a los principios democráticos de convivencia. Todas estas prácticas -que sólo pueden ser adjetivadas como culturales si se adopta la noción de cultura derivada del Volksgeist, pero que serían consideradas prejuicios o costumbres bárbaras por los seguidores de la noción ilustrada, quedan al margen de la acción tuitiva que en favor del progreso de la cultura compete a los poderes públicos.

Nuestra Constitución, pues, no ampara el relativismo cultural que es la consecuencia inexorable de la noción de cultura derivada del Volksgeist. El artículo 27.2 pone de manifiesto la prevalencia del párrafo quinto del Preámbulo sobre el cuarto. La concepción ilustrada se impone, en última instancia, a la romántica. No todo es cultura. El artículo 27.2 estatuye un tribunal $y$ unas normas para determinarlo. Las manifestaciones y prácticas que no obtengan un juicio favorable al respecto, al ser valoradas según los criterios del 27.2, no gozan del amparo que los poderes públicos otorgan a la cultura. $Y$ no gozan de él porque no son cultura, es decir, porque no caben dentro de la noción constitucional de cultura.

Ello implica que por muy integradas en la tradición que se pretendan, por muchos siglos de antigüedad que ciertas prácticas aleguen, si no respetan los principios democráticos y los derechos fundamentales ${ }^{82}$, no encuentran un genérico amparo en el párrafo cuarto del Preámbulo: culturas de los pueblos de España. Y si no lo encuentran ello quiere decir que la noción constitucional de cultura es la contenida en el párrafo quinto: cultura, en singular, como valor con un contenido universal. Cultura como progreso.

82 Lucas Verdú, P.: “El Estado de Cultura no puede consentir los ataques a la dignidad de la persona ni a su integridad moral». Curso..., op. cit., vol. IV, pág. 356. 
El conflicto entre universalismo y particularismo se resuelve. Las dos nociones de cultura son compatibles. $Y$ son compatibles porque el artículo 27.2 subordina una a otra. Se acepta la noción particular (párrafo cuarto) siempre y cuando sea compatible con los valores universales que corresponden a la noción general (párrafo quinto). El pluralismo encuentra sus límites en el progreso. En suma, la Constitución asume la noción universalista de cultura heredera del pensamiento del siglo de las Luces.

\section{CULTURA Y DEMOCRACIA}

La íntima relación existente entre los principios de la educación y la cultura y el régimen político no ha pasado desapercibida a los grandes pensadores políticos desde la Antigüedad hasta la Edad Contemporánea ${ }^{83}$.

ARISTÓTELES advierte en el Libro VII de la Política la importancia de la educación según el régimen político: «Entre todas las medidas mencionadas para asegurar la permanencia de los regímenes políticos es de la máxima importancia la educación de acuerdo con el régimen, que ahora todos descuidan. Porque de nada sirven las leyes más útiles, aun ratificadas unánimemente por todo el cuerpo civil, si los ciudadanos no son entrenados $y$ educados en el régimen... $Y$ la educación orientada desde el punto de vista del régimen no consiste en hacer aquello en que se complacen los que ejercen la oligarquía o los partidarios de la democracia, sino aquello que capacita a los primeros para el ejercicio de la oligarquía y a los otros para gobernarse democráticamente" ${ }^{84}$.

Dos mil años después MONTESQUIEU volvía a insistir en el mismo tema: «En el gobierno republicano se necesita de todo el poder de la educación" ${ }^{85}$. Destacaba el formulador de la teoría de la división de poderes cómo en las democracias el papel que juega la educación es muy superior al que cumple en regímenes monárquicos o aristocráti-

83 Muñoz Arnau, J. A.: La educación política como función de gobierno en el Estado, Eunsa, Pamplona, 1982, págs. 90-198.

${ }_{84}$ Anistóteles, Política, 1310 a. Ed. de J. Marías y M. Araujo. Instituto de Estudios Políticos, Madrid, 1970.

${ }_{85}$ Montesouieu: Del espíritu de las leyes (1735), traducción de M. Blázquez y Pedro de Vega, Tecnos, Madrid, 1985. Libro IV, cap. V, pág. 28. 
cos. Y ello porque el principio en que se basa la democracia es "la virtud": "Se puede definir esta virtud como el amor a las leyes y a la patria. Dicho amor requiere una preferencia continua del interés público sobre el interés de cada cual... Este amor afecta especialmente a las democracias. Sólo en ellas se confía el gobierno a cada ciudadano. Ahora bien, el Gobierno es como todo el mundo: para conservarlo hay que amarlon"

El constituyente percibió esta conexión entre la educación y el régimen político. Tal es el sentido del artículo 27.2 ya comentado. En dicho precepto se constitucionaliza la educación democrática ${ }^{87}$.

Ahora bien, la educación democrática se enmarca en un contexto más amplio: la cultura democrática cuyo progreso proclama el Preámbulo constitucional. Porque cuando el texto preambular se refiere al progreso de la cultura - y es aquí a donde queríamos llegar- está aludiendo al progreso de la cultura democrática. Tal es la conclusión que extraemos de considerar el enunciado preambular del párrafo quinto (el progreso de la cultura) como un requisito o medio indispensable para el logro de una sociedad democrática avanzada. $Y$ es que sin progreso de la cultura democrática difícilmente se producirá un progreso de la sociedad democrática.

El aumento del nivel cultural de la sociedad es, como ya señalara TOCOUEVILLEE ${ }^{88}$, el más poderoso instrumento para el fortalecimiento y consolidación de una sociedad democrática. $Y$ ello porque la democracia exige participación ${ }^{89}$. Y la participación requiere un cierto nivel de cultura cívica. Al mismo tiempo, hay que insistir también en la idea de que la cultura democrática se adquiere principalmente mediante la participación. En este sentido la democracia es escuela de ciudadanía responsable.

86 Montesouieu, Del espíritu..., op. cit., pág. 29.

87 Sobre los orígenes de la educación democrática, Negrín Fajardo, O.: «Introducción" al Informe y proyecto de decreto sobre la organización general de la instrucción pública de Condorcet, Centro de Estudios Ramón Areces, Madrid, 1990, págs. 13 y ss.

${ }_{88}$ "Es indudable que en los Estados Unidos la instrucción del pueblo constituye una poderosa ayuda para el mantenimiento de la República democrática. Así sucederá, creo yo, en todas las partes donde no se separe la instrucción que ilumina el espíritu, de la educación, que regula las costumbres". TOCOUEVILLE, A DE, La democracia en América (1835), traducción de D. Sánchez, Alianza, Madrid, 1993, vol. I, págs. 287-288.

3 Jiménez de Parga, M.: La ilusión política, Alianza, Madrid, 1993, pág. 13. Ramírez, M.: La participación política, Tecnos, Madrid, 1985. 


\section{CONCLUSIONES}

La profusión de preceptos de nuestro texto constitucional dedicados a "lo cultural" confirma el importante papel que el constituyente concedió en 1978 a la Cultura. La Constitución de 1978 es la primera en nuestra historia constitucional que contiene una concepción global, no fragmentaria y dispersa, de la Cultura.

La aparente contradicción entre las distintas concepciones de Cultura que respectivamente extraemos de los párrafos cuarto y quinto del texto preambular se resuelve en el articulado. El párrafo cuarto nos remite al Volksgeist, al romanticismo alemán, y el quinto a la llustración. Ambos encuentran su proyección en los dos principios vertebradores de nuestra Constitución cultural: pluralismo y progreso. Ambos gozan de igual relevancia en el texto preambular. Pero en el texto constitucional, como ya vimos, la primacía se concede al principio de progreso, a la noción ilustrada de cultura. Ello se deduce de que la Constitución no impone límite alguno al desarrollo, al progreso de la cultura, y si lo hace respecto al pluralismo. De hecho, el pluralismo encuentra sus límites en el progreso.

Por último, hay que destacar que la cultura es presupuesto de la democracia, puesto que, dado que "cultura y sociedad están mutuamente imbricados ${ }^{90}$, es imposible que subsista una sociedad democrática sin una "cultura democrática". En este sentido, hay que decir que el establecimiento de una auténtica cultura democrática en nuestro país es, como señala el profesor RAMíREZ, la asignatura pendiente de nuestra democracia ${ }^{91}$. Y las consecuencias de que no la aprobemos pueden resultar a largo plazo muy graves. En el citado artículo se dice: "La cultura cívica enseña a no engañar al Estado, teniéndolo como algo propio. Y aquí desde los años de estraperlo a los fraudes en la declaración de la renta, ha habido una continua tendencia: al Estado siempre hay que intentar engañarlo. Como el amiguismo impera en todos los sectores de la vida social y el tráfico de influencias resulta moneda común en el toma y daca de la vida cotidiana». No le falta razón al profesor RAMÍREZ en su diagnóstico de nuestra sociedad. Es evidente que ésta no posee una cultura democrática fundamentada en la "virtud" de Montesquieu. En este sentido la lucha por consolidar en España una cultura cívica es inescindible de la lucha por la democracia,

90 Torres del Moral, A.: Principios de..., op. cit., vol. l, pág. 85.

91 Ramirez, M.: "Corrupción y sociedad", El País, 6 de junio de 1994. 
entendida ésta como una meta que nunca se alcanza. Como un continuo proceso cuyo fin nunca vislumbraremos ${ }^{92}$.

La conclusión que extraemos de todo lo anterior es que la fórmula constitucional "progreso de la cultura" nos remite a la idea de progreso o profundización de la democracia. La relación que hemos establecido entre cultura y democracia nos permite, por último, afirmar que la dimensión cultural de la Constitución, dimensión que he pretendido explicar en esta exposición, le es consustancial. Es decir, que la Constitución democrática - la única que puede ser considerada como auténtica Constitución- ${ }^{93}$ tiene un componente cultural del cual no puede, en modo alguno, prescindir. Solamente profundizando en esa dimensión llegará esa edad de oro cultural a la que el ilustrado francés Condorcet se refería en la cita con la que he iniciado este trabajo: "Llegará un tiempo en el que la cultura se habrá extendido con igualdad y sobre todos los lugares de un mismo territorio y entre todas las clases de una misma sociedad; en el que todas las ciencias y todas las aplicaciones de la ciencia se habrán emancipado igualmente del yugo de todas las supersticiones o del veneno de las falsas doctrinas; en el que cada hombre, en fin, encontrará en sus propios conocimientos, en la rectitud de su espíritu, armas suficientes para rechazar todas las añagazas de la charlatanería; pero estos tiempos están lejanos aún; nuestra finalidad debe ser prepararlos, acelerar su advenimiento" ${ }^{94}$.

92 Sobre la democracia como proceso: Diaz, E.: Estado de Derecho y sociedad democrática, Taurus, Madrid, 1981, págs. 86 y 153. Peces Barba, G.: Los valores superiores, Tecnos, Madrid, 1984, pág. 65. Boввіо, N.: El futuro de la democracia, FCE, México, 1986, pág. 7. CARRo, A.: "La democracia verdadera", en Revista de Administración Pública, n. ${ }^{\circ}$ 100-102, 1983, pág. 185. De Esteban, J., y López Guerra, L.: El régimen constitucional español, Labor, Barcelona, 1980, tomo I, págs. 64, 87 y 117. Aragón Reyes, M.: Constitución y Democracia, Tecnos, Madrid, 1989, pág. 138...; etc.

93 Aragón, M.: Constitución y Democracia, Tecnos, Madrid, 1989, pág. 25.

94 CONDORCET: Informe y proyecto de decreto sobre la organización general de la instrucción pública, edición de O. Negrin, Centro de Estudios Ramón Areces, Madrid, 1990, págs. 94-95. 